\title{
In-vivo studies of mammary development in the goat using magnetic resonance imaging (MRI)*
}

\author{
P. A. Fowler $\dagger$, C. H. Knight $\ddagger$, G. G. Cameron and M. A. Foster \\ Department of Bio-Medical Physics \& Bio-Engineering, University of Aberdeen, \\ Aberdeen AB9 2ZD, UK and $\$$ Hannah Research Institute, Ayr KA6 5HL, UK
}

\begin{abstract}
Summary. Mammary development and regression were measured in goats in vivo using magnetic resonance imaging (MRI). Measurements were made during the first and second cycles of pregnancy, lactation and involution.

In primiparous goats, an exponential pattern of growth was evident during gestation and for the first 2 weeks of lactation. Parenchyma volume correlated significantly with milk yield across goats during early lactation, and across stage of lactation within goats. Milking was discontinued in Week 26 of the first lactation. Involution was characterized by an initial accumulation of fluid (over 2 days) followed by reabsorption; parenchyma volume did not decrease significantly until the 3rd week of involution, which was also the time at which these goats were mated to start their second gestation. Their udders still contained significant quantities of fluid $(40-60 \%$ of the gross volume), but parenchyma volume was also greater (by $4 \cdot 7$-fold) than in goats beginning their first gestation. By Week 15 of gestation there was no longer a parity difference in parenchyma; the udders of first-gestation goats had grown significantly, but those of second-gestation goats had not. Conversely, between gestation Week 15 and laction Week 2 mammary growth was significantly more rapid in the second cycle, such that the udder was larger at the start of the second lactation.
\end{abstract}

Keywords: mammogenesis; mammary gland; lactation; pregnancies; goats; MRI

\section{Introduction}

During its development, the mammary gland undergoes marked changes not only in size but also in its internal structure and composition, as secretory epithelium (parenchyma) gradually displaces fatty stroma. Most studies of this process (mammogenesis) have been conducted in laboratory species, and have involved killing groups of animals at intervals during the lactation cycle for post-mortem analysis of the mammary tissue. Parellel studies in dairy species are prohibitively expensive. It is possible to minimize animal numbers, for instance by using identical twins (Swanson \& Poffenbarger, 1979), but the availability of such animals is a limiting factor. An alternative approach is the serial in-vivo study of each individual animal on several occasions, but until recently the problem with this method was the limited amount of information that could be obtained. Simple determinations of gross udder volume by water displacement or plaster cast (Linzell, 1966) took no account of the changes in internal composition. Combining udder volume with tissue biopsy alleviated this problem to some extent (Knight \& Peaker, 1984), but only when the biopsy sample could be shown to be representative of the whole gland (essentially late pregnancy and throughout lactation). Taking larger samples (e.g. the whole of one gland, Cowie 
et al., 1965) brought its own problems, through the possible stimulation of compensatory growth responses (Knight, 1987).

Body imaging techniques enable the study of internal structure as well as gross size. Sorensen $e t$ al. (1987) used X-ray computed tomography (X-ray CT) to study mammogenesis in peri-pubertal heifers, although size limitations meant that these measurements had to be made in vitro. Goats, on the other hand, are a suitable size for in-vivo study, and some X-ray CT data have been obtained on whole-body composition (Sorensen, 1984). Fowler et al. (1990) have reported the efficacy of proton magnetic resonance imaging (MRI) for monitoring mammary development in goats. Estimates of mammary parenchyma volume were highly correlated with parenchyma weight determined post mortem, irrespective of changes in the parenchyma:stroma ratio within the gland. It appeared that the method would be useful for studying caprine mammogenesis in vivo and essentially non-invasively. We now present the results of such a study.

\section{Materials and Methods}

Animals. Female British Saanen goats housed at the Rowett Research Institute were used in their first or second lactation cycle. Pregnant goats received hay and water ad libitum, lactating goats additionally received $500-2000 \mathrm{~g}$ concentrate diet/day (goat-mix 1, Edinburgh School of Agriculture), depending on stage of lactation. Lactating goats were milked twice-daily at approximately $08: 00$ and 16:00 h, and the yield of milk was recorded.

Magnetic resonance imaging. The goats were imaged using the Aberdeen Mk.I NMR imager operating at a magnetic field strength of 0.04 Tesla, following the standard protocol described by Fowler et al. (1990).

Experimental design. A total of 10 goats were imaged. Five were imaged at intervals of 3-6 weeks during their first gestation (gestation length is 21.5 weeks in goats), 6 were imaged during their first lactation, which lasted for 26 weeks, and 3 of these were imaged during 3 weeks of post-lactational involution, at which point they were mated. These constituted part of the group of 5 goats which were imaged during their second gestation, and these same 3 goats were then imaged during their second lactation, which again lasted for 26 weeks. Data for each reproductive cycle were obtained during more than 1 year, but since there was no statistical difference between results from the different years, the data were pooled. Details of imaging times and animal numbers are given in Table 1.

Table 1. Number of observations at each time point

\begin{tabular}{|c|c|c|c|c|}
\hline \multicolumn{3}{|c|}{ Week of: } & \multicolumn{2}{|c|}{$\begin{array}{l}\text { Reproductive } \\
\text { cycle }\end{array}$} \\
\hline Gestation & Lactation & Involution & lst & 2nd \\
\hline 3 & & & 3 & 3 \\
\hline 7 & & & 5 & 3 \\
\hline 10 & & & 2 & 2 \\
\hline 15 & & & 2 & 5 \\
\hline 17 & & & 5 & 5 \\
\hline 19 & & & 5 & 4 \\
\hline 21 & & & 5 & 2 \\
\hline & 2 & & 6 & 3 \\
\hline & 5 & & 3 & 3 \\
\hline & 8 & & 6 & 3 \\
\hline & 12 & & 5 & 3 \\
\hline & 24 & & 5 & 3 \\
\hline & & 0.3 & 3 & - \\
\hline & & 1 & 3 & - \\
\hline & & 2 & 3 & - \\
\hline & & 4 & 3 & - \\
\hline
\end{tabular}


Image analysis. The MRI images were analysed using the method of Fowler et al. (1990) to yield an estimate of mammary parenchyma volume. Fluid retained in the udder was excluded from this analysis using interactive editing. Determinations were also made of whole-udder and parenchyma T1 NMR relaxation times. The latter reflects the water content, and hence developmental state, of the tissue.

Statistical analysis. Differences between means were tested by paired $t$ test within lactation cycles, and by unpaired $t$ test across lactation cycles. Relationships between variables were examined by least-squares linear regression and correlation coefficient; differences between slopes were tested using the F-test.

\section{Results}

\section{Mammary development in the first gestation}

Mammary volume data for gestation and the start of lactation are shown in Table 2 . At the start of the first gestation mammary parenchyma volume was very small, and in the 3 goats studied at this stage the glands did not contain any fluid. There was some variability between animals in this respect; the udder of one goat imaged for the first time in Week 6 was engorged with fluid, which was largely reabsorbed over the next 4 weeks. Parenchyma volume increased progressively throughout the first gestation, such that just before parturition it was $16 \cdot 8$-fold greater than at Week 3. The increase in parenchyma volume appeared to be exponential (Fig. 1a). An exponential plot of the mean data (time from mating vs ln. parenchyma volume) gave a correlation coefficient of 0.99 (Fig. 1b), with parenchyma growth described by the relationship $y=0 \cdot 157 x+3 \cdot 825$, where $y$ is natural logarithm of parenchyma volume and $x$ is week of gestation. Calculations from the slope gave a time for volume to double of $4 \cdot 3$ weeks.

Table 2. Mammary gland volumes at various stages of the first and second gestations of goats

\begin{tabular}{|c|c|c|c|c|c|c|c|c|c|}
\hline & \multirow{2}{*}{$\begin{array}{c}\text { Gestation } \\
\text { no. }\end{array}$} & \multicolumn{8}{|c|}{ Weeks after conception } \\
\hline & & 3 & 7 & 10 & 15 & 17 & 19 & 21 & $23 \dagger$ \\
\hline Total volume (ml) & $\begin{array}{l}1 \\
2\end{array}$ & $\begin{array}{c}77 \\
\pm 13 \\
701^{*} \\
\pm 56\end{array}$ & $\begin{array}{r}189 \\
\pm 46 \\
677^{*} \\
\pm 107\end{array}$ & 271 & $\begin{array}{r}403 \\
654 \\
+128\end{array}$ & $\begin{array}{r}1177 \\
\pm 218 \\
1145 \\
\pm 132\end{array}$ & $\begin{array}{r}1864 \\
\pm 193 \\
2000 \\
\pm 581\end{array}$ & $\begin{array}{r}2490 \\
\pm 187 \\
3055\end{array}$ & $\begin{array}{r}1711 \\
\pm 289 \\
2056 \\
\pm 129\end{array}$ \\
\hline Fluid volume (ml) & 1 & $\begin{array}{c}337^{*} \\
\pm 78\end{array}$ & $\begin{array}{c}51 \\
\pm 25 \\
338 * \\
\pm 138\end{array}$ & 29 & $\begin{array}{r}243 \\
\pm 97\end{array}$ & $\begin{array}{r}331 \\
\pm 117 \\
318 \\
\pm 32\end{array}$ & $\begin{array}{r}807 \\
\pm 222 \\
806 \\
\pm 458\end{array}$ & $\begin{array}{r}1195 \\
\pm 318 \\
673\end{array}$ & 0 \\
\hline Parenchyma volume (ml) & $\begin{array}{l}1 \\
2\end{array}$ & $\begin{array}{c}77 \\
\pm 13 \\
364^{*} \\
\pm 30\end{array}$ & $\begin{array}{c}138 \\
\pm 23 \\
340^{*} \\
\pm 48\end{array}$ & 241 & $\begin{array}{r}412 \\
\pm 84\end{array}$ & $\begin{array}{r}846 \\
+109 \\
827 \\
+149\end{array}$ & $\begin{array}{r}1057 \\
\pm 168 \\
1194 \\
\pm 250\end{array}$ & $\begin{array}{r}1296 \\
+269 \\
2381\end{array}$ & $\begin{array}{r}1711 \\
\pm 289 \\
2056 \\
\pm 129\end{array}$ \\
\hline
\end{tabular}

Values are mean \pm s.e.

${ }^{*} P<0.001, t$ test, $v S$ Ist gestation.

+Week 2 of lactation.

The first significant accumulation of fluid within the udder occurred at 17 weeks of gestation. Between then and parturition there was a further 3-fold increase, such that fluid then constituted $48 \%$ of the total udder volume (parenchyma volume + fluid volume).

Data for whole-udder and parenchyma $\mathrm{T} 1$ relaxation times are shown in Fig. 2. Lactating mammary tissue has a T1 value intermediate between fatty tissues (low T1) and fluid-rich tissues (high T1). At the start of gestation the parenchyma T1 value was significantly less than that subsequently found in early lactation $(221 \pm 2$ versus $274 \pm 6 \mathrm{msec}, P<0.001)$, reflecting the immature

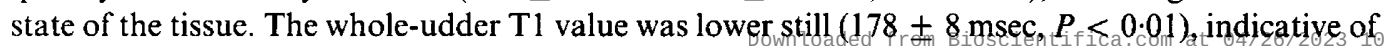



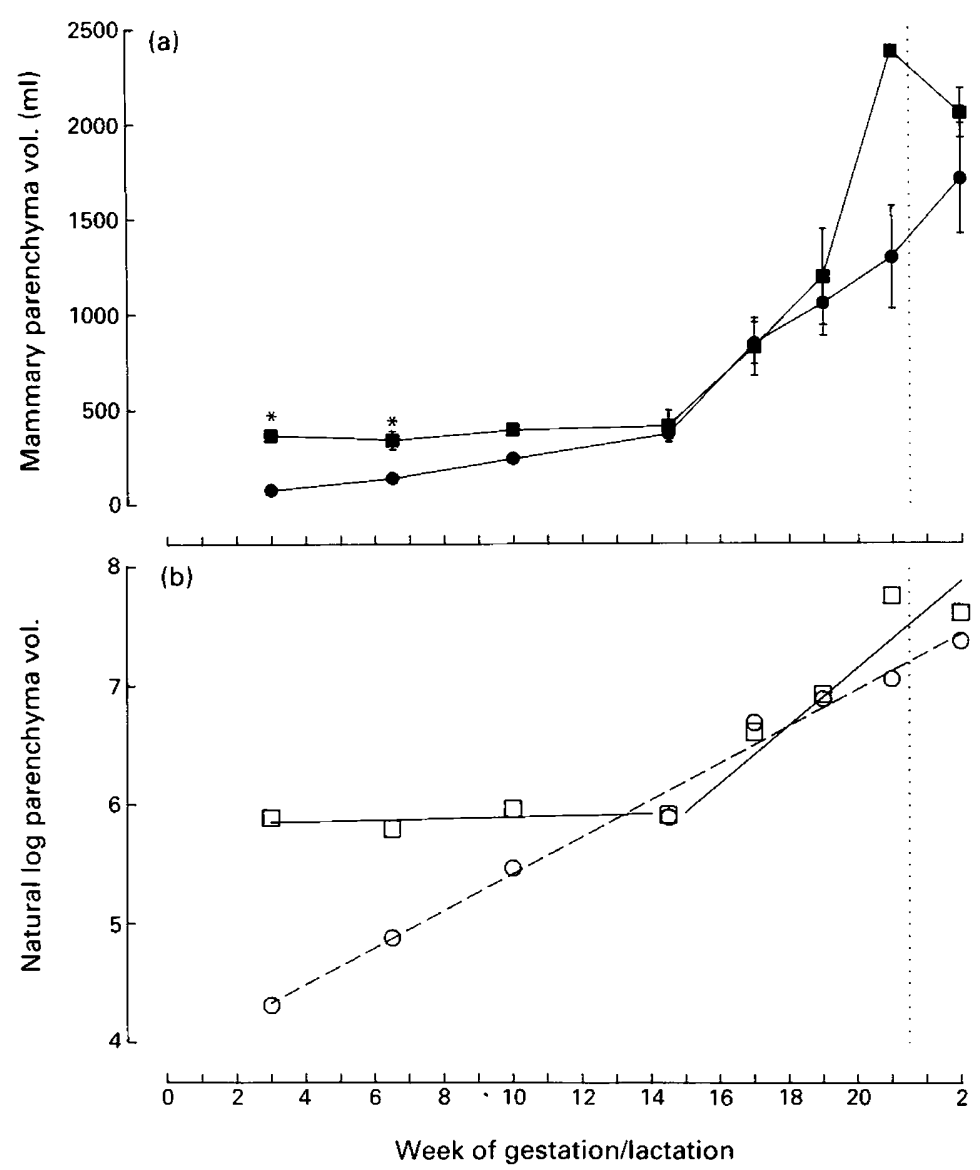

Fig. 1. The pattern of increase in mammary parenchyma volume during the first $(\bullet)$ and second ( $\boldsymbol{\square}$ ) gestations of goats, and during early lactation. (a) Each point is the mean of 2-6 animals (Table 1 for details) with s.e. when appropriate. (b) Exponential plot of the data to show the different patterns of development in the two gestations. Dotted line indicates parturition. $\star P<0.001$ vs first gestation $(t$ test $)$.

a high proportion of adipose tissue in the gland. Whole-gland and parenchyma $\mathrm{T} 1$ both increased gradually during the first 15 weeks of gestation. There was no further change in parenchyma $\mathrm{T} 1$ after Week 15 , but the whole-gland value increased markedly as pre-partum fluid accumulated in the udder before parturition.

\section{Mammary development in the first lactation}

Paired parenchyma volume data were available from late gestation (Week 21) and early lactation (Week 2) for 4 goats. In all 4, volume increased during this interval, by approximately $400 \mathrm{ml}$, or $24 \%$ of the final volume. This increase was significant $(P<0.05$, paired $t$ test $)$. Week 2 of lactation is included in the exponential growth plot (Fig. 1b).

Six goats were imaged during early lactation (Weeks 2 and 8), and although parenchyma volume increased in 3 of these, the overall mean value remained constant between Weeks 2 and 8 (Fig. 3). Thereafter parenchyma volume declined significantly, and at the end of lactation (Week 24) was $61 \%$ of its week 8 value $(P<0.05)$. 

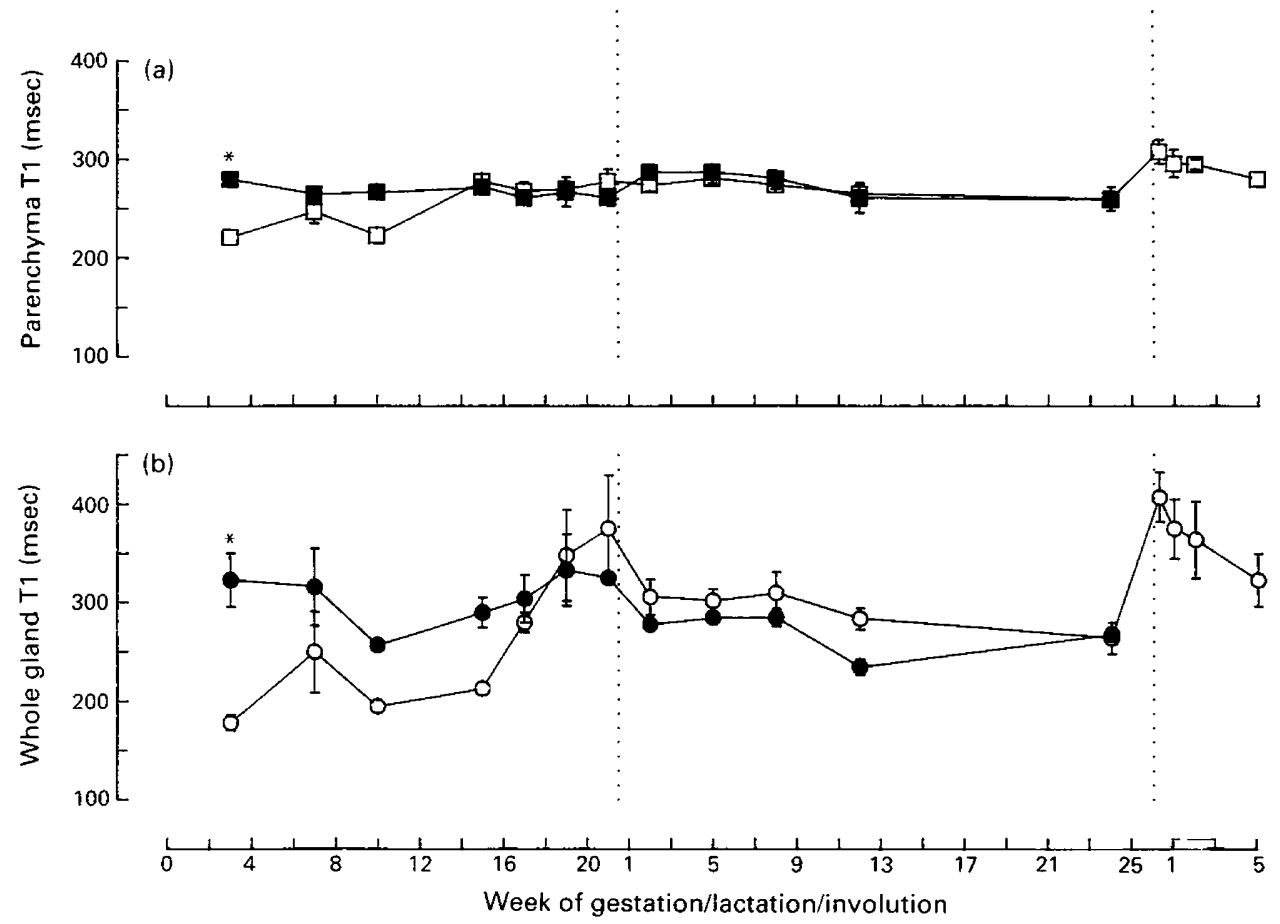

Fig. 2. Parenchyma (a) and whole-udder (b) T1 relaxation-time values for the first and second lactation cycles of goats. Each point is the mean of 2-6 animals (Table 1 for details) with s.e. when appropriate. Open symbols are first lactation cycle, closed symbols are second. Dotted lines indicate parturition (left) and cessation of milking (right). ${ }^{*} P<0.01$ vs first gestation ( $t$ test).

Milk yield showed the normal pattern of an initial increase to a peak value at around Week 5, followed by a plateau and then a gradual decline (Fig. 3). As a function of parenchyma volume, milk yield varied relatively little during lactation. The overall mean value was $1.46 \pm 0.09 \mathrm{~g} \mathrm{milk} / \mathrm{ml}$ parenchyma volume/day. The maximum value $(1.58 \pm 0.17 \mathrm{~g} / \mathrm{ml} /$ day $)$ was obtained in Week 12 , but this was not significantly different from Week $2(1 \cdot 36 \pm 0 \cdot 1)$ or Week $24(1 \cdot 39 \pm 0 \cdot 22 \mathrm{~g} / \mathrm{ml} /$ day $)$. Not surprisingly, therefore, milk yield correlated very well with parenchyma volume over the whole lactation $(r=0.82, P<0.001)$. Although much of this relationship was a function of lactation stage, yield also correlated with parenchyma volume across goats within an individual week. This relationship wasstrongest at Week $2(r=0.93, P<0.05, N=6)$, still evident at Week $8(r=0.87$, n.s., $N=6)$ but totally absent in Week 24 .

Parenchyma T1 remained essentially constant at between 260 and $280 \mathrm{msec}$ throughout lategestation and the whole of lactation (Fig. 2). Whole-udder T1 decreased by approximately $20 \%$ between late gestation and early lactation, and by a further $15 \%$ during the course of lactation (306 \pm 18 to $264 \pm 16 \mathrm{msec}, P<0.05$ ). Nevertheless, it remained significantly higher than parenchyma T1 from parturition until Week 12 of lactation $(P<0.05)$.

\section{Post-lactational mammary involution}

Within 2 days of the cessation of milking, the volume of retained fluid had risen to more than twice parenchyma volume (Fig. 3). This fluid was largely reabsorbed over the next 12 days, but at no stage did it disappear completely. Mammary parenchyma volume did not change significantly 

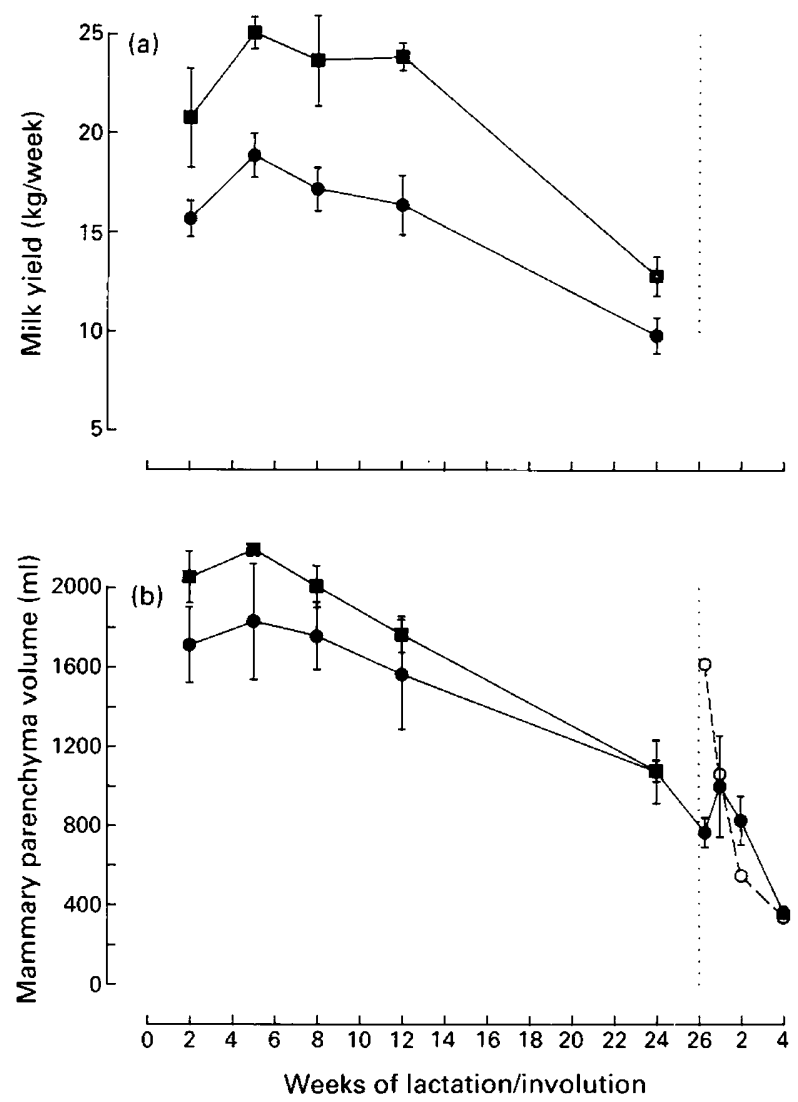

Fig. 3. The pattern of change in milk yield (a) and mammary volumes (b) during the first (๑) and second $(\boldsymbol{U})$ lactations of goats, and during post-lactational involution. Each point is the mean of 2-6 goats (Table 1 for details) with s.e. when appropriate. In (b) solid symbols are mammary parenchyma volume and open symbols are total udder volume, including retained fluid. Dotted line indicates cessation of milking.

until Day 28 of involution, at which time it was significantly reduced (to $41 \%$ of its late lactation value, $P<0.001$, paired $t$ test).

Parenchyma T1 increased from $260 \pm 12$ to $308 \pm 12 \mathrm{msec}(P<0.05)$ after the last milking, and then declined such that at 4 weeks of involution it was not significantly different from its lactation value. Whole-udder T1 increased markedly ( $264 \pm 16$ to $407 \pm 25 \mathrm{msec}, P<0.01$ ), correlating with the increase in retained fluid, and although it subsequently declined it did not revert totally to its lactation value (Fig. 2).

\section{Mammary development during the second lactation cycle}

Involution was incomplete at the end of the first lactation, in that goats started their second gestation with more mammary parenchyma than did first-gestation goats $(364 \pm 30 v s 77 \pm 13 \mathrm{ml}$, $P<0.001, t$ test). Retained fluid was also higher (Table 2). The pattern of parenchyma growth was different from that observed in the first gestaion (Fig. 1). Parenchyma volume did not increase until after Week 15 of the second gestation, by which time there was no longer any parity-related difference (Table 2, Fig. 1). Up until this time the rate of increase in parenchyma volume was significantly greater in the first gestation goats (from Fig. $1 \mathrm{~b}$, calculated slopes of 0.16 and 0.007 for first 
and second gestations respectively, $P<0.001, \mathrm{~F}$ test). After Week 15 this situation was reversed; from the slopes in Fig. 1(b) the calculated increases in parenchyma volume between Week 15 and parturition were $967 \mathrm{ml}$ (first gestation) and $1238 \mathrm{ml}$ (second gestation), doubling time was reduced from 4.3 weeks (first gestation) to 3.6 weeks (second gestation) and the exponential slopes were 0.16 (first gestation; unchanged from early gestation) and 0.23 (second gestation; significantly greater than early gestation and late first gestation, $P<0.01$, F test). These differences are evident in Fig. 1(b).

Unlike in the first cycle, there was no significant difference in mean parenchyma volume between Week 21 of the second gestation and Week 2 of the second lactation. Parenchyma volume was greater in the second lactation than in the first from Week 2 (20\% difference) through to Week 12 (13\% difference; Fig. 3). Milk yield was also greater at these times, by $32 \%$ and $46 \%$ respectively. Milk production tended to be more efficient in the second lactation; yield per ml parenchyma was higher throughout lactation (mean value of $1.65 \pm 0.07 \mathrm{vs} 1.46 \pm 0.09 \mathrm{~g} / \mathrm{ml} /$ day for the first lactation, n.s.) but direct comparison in those goats for which data was available from both lactations did not reveal a significant effect. The small number of animals studied in the second lactation did not permit an analysis of the size:yield correlation.

Whole-udder and parenchyma T1 were both significantly higher at the start of the second gestation than at the start of the first $(P<0.01)$. By 7 weeks of gestation the parenchyma values had converged, but a whole-udder difference persisted until late gestation (Fig. 2). During early lactation whole-udder $\mathrm{T} 1$ tended to be lower in the second cycle, perhaps indicating a more efficient milk-ejection reflex in these older animals.

\section{Discussion}

This study has demonstrated the feasibility of using a whole-body imaging technique to generate quantitative data with a serial approach employing relatively few animals. With the exception of one goat who contracted mastitis and died during the study, all of the goats finished the trial in a fit and healthy condition. The accuracy of the MRI procedure has been addressed in a previous study (Fowler et al., 1990). Although MRI overestimates parenchyma, it does so by a constant amount; the two measurements are significantly correlated $(r=0.88, P<0.001)$ and the accuracy is unaffected by variation in the relative proportions of parenchyma and stroma. This is the first time that an imaging technique has been used to monitor mammogenesis in vivo. The closest parallel is the work of Sejrsen et al. (1986) and Sorensen et al. (1987) who used X-ray CT to assist in the invitro analysis of heifer mammary glands following nutritional and endocrinological manipulation of peri-pubertal mammary growth.

MRI not only provided measurements of parenchyma growth, but also, through the T1 data, yielded information on tissue differentiation. For example, the relatively fatty, undifferentiated gland of early pregnancy exhibited a lower $\mathrm{T} 1$ value than did differentiated lactating parenchyma. Similarly, $\mathrm{T} 1$ values demonstrated that the udder started the second gestation in a condition different from that at the start of the first gestation.

The demonstration of exponential growth during pregnancy confirms numerous other studies, mainly in laboratory species (Knight \& Peaker, 1982; Sheffield \& Anderson, 1985). Anderson et al. (1981) killed groups of goats at various stages of gestation, for analysis of mammary tissue. They observed an exponential increase in the mammary cell population (DNA) with a population doubling time of approximately 7 weeks. This compares with our measurement of 4.3 weeks for parenchyma volume to double. Since mammogenesis consists of cellular hypertrophy as well as hyperplasia (Foster, 1977), this difference is not surprising. Anderson et al. (1981) also suggested that growth continued during early lactation, an observation later supported by mammary biopsy data (Knight \& Peaker, 1984) and now by the present primiparous goat results. Although the peak 
in parenchyma volume coincided with peak milk yield in some of our goats, the overall results confirm the previous reports that growth ceases after Week 2 , several weeks before maximum yield is attained.

The way in which the mammary gland redevelops during a second gestation will vary according to the particular reproductive strategy adopted (reviewed by Knight, 1989). Animals which do not conceive until lactation and post-lactational involution are completed will have the whole of the subsequent gestation for mammary redevelopment, but those conceiving earlier than this will have a proportionately reduced interval between the end of one lactation and the beginning of the next. Ways in which redevelopment might be altered to accommodate this shorter interval include a reduced degree of involution (i.e. more carry-over of tissue between lactations), an increased growth rate, and redevelopment commencing before the first lactation finishes or continuing into the second lactation to a greater extent than normal (or both).

In this study, the pattern of mammary growth was quite clearly different in the two gestations. Initially, this was a consequence of the different starting points; the gland did not involute after the first lactation to its virgin state, but instead goats started their second pregnancy wih significantly more parenchyma than did primiparous goats. However, this is not definitive evidence for increased carry-over of tissue, since the absence of any increase in parenchyma volume during the first 15 weeks of the second gestation suggests that involution of the existing secretory tissue may well have been continuing at the same time as new cells were proliferating. Unfortunately this cannot be confirmed, since cell proliferation rates were not determined.

We did obtain evidence for an increased growth rate late in the second gestation. This has considerable significance, since it indicates that there is not an innate and inflexible rate of mammogenesis within a given species. Knight (1989) suggested that mammary growth is a remarkably adaptable process, and this observation supports that argument. We did not, however, obtain any evidence to suggest that post-parturient mammary development was greater in the second reproductive cycle than the first.

A positive correlation has been demonstrated between gross udder volume and milk yield in goats at peak lactation (Linzell, 1966), in sheep (Davis et al., 1980) and cows (Davis et al., 1985). Gross udder volume provides a less accurate estimate of functional tissue mass than does MRI, since it cannot take account of variations in the relative proportions of parenchyma and stroma (Fowler et al., 1990). The correlation between milk yield and the MRI estimate of parenchyma volume was significant at Week 2 of the first lactation, but subsequently deteriorated. This suggests that the increase in milk yield between parturition and peak lactation was more a consequence of cell differentiation than of growth of parenchyma; the same conclusion was reached by Wilde $e t$ al. (1986) on the basis of mammary enzyme determinations, which increased by as much as 24-fold during this period. In a comparative analysis across species, Linzell (1972) obtained an average milk production index of approximately $2 \mathrm{ml} \mathrm{milk/g} \mathrm{mammary} \mathrm{tissue} \mathrm{per} \mathrm{day.} \mathrm{Our} \mathrm{value} \mathrm{was} \mathrm{some-}$ what less (around $1.5 \mathrm{ml} / \mathrm{g}$ parenchyma volume per day), but we have shown previously that parenchyma weight determined post mortem is only $71 \%$ of the MRI estimate (Fowler et al., 1990). Appropriate correction of the present data results in a very similar production index $(2.1 \mathrm{ml} / \mathrm{g} /$ day $)$ to that found by Linzell (1972).

The effect of parity and age on milk yield is well documented, particularly in dairy cattle. In the present study, second-lactation goats produced significantly more milk than did their firstlactation counterparts. By contrast, the only information on mammary size in successive lactations comes from guinea-pigs (Anderson \& Sheffield, 1983), in which a linear increase in mammary DNA was observed over the first 6 reproductive cycles. Our quantitative data for lactating goats show that parenchyma volume was indeed larger at the start of the second lactation (by about $20 \%$ ).

This study was funded by AFRC Link-group grant no. LRG23. We thank I. Brown, A. Docherty, L. L. Hutcheon, A. Law and P. Ross for excellent technical assistance. 


\section{References}

Anderson, R.R., Harness, J.R., Snead, A.F. \& Salah, M.S. (1981) Mammary growth pattern in goats during pregnancy and lactation. J. Dairy Sci. 64, 427-432.

Anderson, R.R. \& Sheffield, L.G. (1983) Growth of guinea pig mammary glands through their first six lactations. J. Dairy Sci. 66, 29-34.

Cowie, A.T., Cox, C.P., Folley, S.J., Hosking, Z.D., Naito, M. \& Tindal, J.S. (1965) The effects of the duration of treatments with oestrogen and progesterone on the hormonal induction of mammary growth and lactation in the goat. J. Endocr. 32, 129-139.

Davis, S.R., Hughson, G.A., Bryant, A.M. \& McKenzie, D.D.S. (1985). A physiological basis of genetic improvement in milk production of Friesen \& Jersey cows. Proc. N.Z. Soc. Anim. Prod. 45, 21-25.

Davis, S.R., Hughson, G.A., Farquhar, P.A. \& Rattray, P.V. (1980) The relationship between the degree of udder development and milk production in coopworth ewes. Proc. N.Z. Soc. Anim. Prod. 40, 163-165.

Fowler, P.A., Knight, C.H., Cameron, G.G. \& Foster, M.A. (1990) The use of magnetic resonance imaging (MRI) in the study of goat mammary glands in vivo. J. Reprod. Fert. 89, 359-366.

Foster, R.C. (1977) Changes in mouse mammary epithelial cell size during mammary gland development. Cell Differentiation 6, 1-8.

Knight, C.H. (1987) Compensatory changes in mammary development and function after hemimastectomy in lactating goats. J. Reprod. Fert. 79, 343-352.

Knight, C.H. (1989) Constraints on frequent or continuous lactation. Proc. Nutr. Soc. 48, 45-51.

Knight, C.H. \& Peaker, M. (1982) Mammary cell proliferation in mice during pregnancy and lactation in relation to milk yield. $Q$. Jl exp. Physiol. 67, 165-177.
Knight, C.H. \& Peaker, M. (1984) Mammary development and regression during lactation in goats in relation to milk secretion. $Q$. $J$ lexp. Physiol. 69, 331-338.

Linzell, J.L. (1966) Measurement of udder volume in live goats as an index of mammary growth and function. J. Dairy Sci. 49, 307-311.

Linzell, J.L. (1972) Milk yield, energy loss in milk, and mammary gland weight in different species. Dairy Sci. Abstr. 34, 351-360.

Sejrsen, K., Foldager, J., Sorensen, M.T., Akers, R.M. \& Bauman, D.E. (1986) Effect of exogenous bovine somatotrophin on pubertal mammary development in heifers. J. Dairy Sci. 69, 1528-1533.

Sheffield, L.G. \& Anderson, R.R. (1985) Interspecies variation in mammary gland growth rate; relation to gestation length. J. Dairy Sci. 68, 2571-2579.

Sorensen, M.T. (1984) Computerized tomography of goats during pregnancy and lactation. In In Vivo Measurement of Body Composition in Meat Animals, pp. 75-83. Ed. D. Lister. Elsevier, London.

Sorensen, M.T., Sejrsen, K. \& Foldager, J. (1987) Estimation of pubertal mammary development in heifers by computed tomography. J. Dairy Sci. 70, 265-270.

Swanson, E.W. \& Poffenbarger, J.I. (1979) Mammary gland development of dairy heifers during their first gestation. J. Dairy Sci. 62, 702-714.

Wilde, C.J., Henderson, A.J. \& Knight, C.H. (1986) Metabolic adaptations in goat mammary tissue during pregnancy and lactation. J. Reprod. Fert. 76, 289-298.

Received 13 November 1989 